\title{
Two genetically-distinct and differentially- regulated aconitases (AcnA and AcnB) in Escherichia coli
}

\author{
Megan J. Gruer and John R. Guest
}

Author for correspondence: John R. Guest. Tel: +44742 824406. Fax : +44 742728697.

The Krebs Institute for Biomolecular Research, Department of Molecular Biology and Biotechnology, University of Sheffield, PO Box 594, Firth Court, Western Bank, Sheffield S10 $2 \mathrm{UH}, \mathrm{UK}$

\begin{abstract}
An acnA mutant of Escherichia coli was constructed by replacing the chromosomal acnA gene by an internally deleted derivative containing a kan ${ }^{R}$ cassette. Southern and Western blotting confirmed that the acnA gene had been replaced by the disrupted gene and that the aconitase $A$ protein was no longer expressed. However, the mutant failed to exhibit the anticipated glutamate auxotrophy and it retained a residual aconitase activity. This activity was due to an analogous unstable enzyme(s) designated aconitase B. Studies on the regulation of aconitase $A$ synthesis using an acnA-lacz translational fusion showed that the acnA gene resembles other citric acid cycle genes in being subject to CRP-mediated catabolite repression and ArCAmediated anaerobic repression. In addition to being activated by the SoxRS oxidative stress regulatory system, the acnA gene appeared to be activated by the ferric uptake regulator (Fur). It was concluded that the acnA gene belongs to at least four global regulatory networks, crp, arcA, fur and soxRS. In contrast, the aconitase B activity decreased after exposure to oxidative stress and was less affected by anaerobiosis. Comparable studies with the fumarase genes (fumA, B and $C$ ) indicated that fumA (encoding the unstable aerobic iron-sulphur-containing fumarase) is activated by the ferric uptake regulator (Fur) and fumC (encoding the stable fumarase) is activated by the SoxRS oxidative stress regulatory system.
\end{abstract}

Keywords: aconitase, Escherichia coli, citric acid cycle, fumarase, Fur-mediated transcriptional regulation

\section{INTRODUCTION}

Aconitase (EC 4.2.1.3) is a dehydratase-hydratase which catalyses the reversible isomerization of citrate and isocitrate via cis-aconitate in the citric acid and glyoxylate cycles. It is a monomeric enzyme with an essential but redox-inactive $[4 \mathrm{Fe}-4 \mathrm{~S}]$ centre. Until recently, very little was known about the aconitase of Escherichia coli and no aconitase-deficient mutants of E. coli had been isolated. However, sufficient enzyme was purified to raise a specific antiserum for use in screening $\lambda-E$. coli gene libraries for phages expressing the aconitase gene, acn $A$ (Prodromou et al., 1991). The acn $A$ gene was located at $28 \mathrm{~min}$ $(1350 \mathrm{~kb})$ in the E. coli linkage map and the enzyme activity could be amplified up to 200 -fold in plasmidcontaining strains. The primary structure deduced from the nucleotide sequence of the acn $A$ gene (Prodromou et al., 1992) predicted that the E. coli enzyme has the same underlying structure as the porcine mitochondrial aconitase (Robbins \& Stout, 1989), with $29 \%$ amino acid sequence identity and conservation of 19 out of 20 activesite residues, including three cysteine residues involved in ligand binding to the $[4 \mathrm{Fe}-4 \mathrm{~S}]$ centre. Interestingly, the $E$. coli enzyme exhibited $53 \%$ sequence identity with the iron-responsive element binding protein (IRE-BP) or iron regulatory factor (IRF), the mammalian iron-responsive translational regulator which has since been identified as a cytoplasmic aconitase (Kaptain et al., 1991; Kennedy et al., 1992). It has been shown that mammalian tissues can interconvert the cytoplasmic aconitase and RNA-binding activities according to iron availability (Constable et al., 1992; Haile et al., 1992a; EmeryGoodman et al., 1993). However, this functional switch is not associated with a simple [4Fe-4S] to [3Fe-4S] interconversion, but seemingly with a more extensive degradation of the iron-sulphur clusters, in order to accommodate the iron-responsive elements of relevant transcripts in the active-site cleft (Haile et al., 1992b). 
Several E. coli (de)hydratases which contain [4Fe-4S] clusters are particularly susceptible to inactivation by superoxide, including aconitase, fumarase $\mathrm{A}$, and 6phosphogluconate dehydratase (Gardner \& Fridovich, 1991; Liochev \& Fridovich, 1992). It is envisaged that the inactivation of these iron-sulphur enzymes occurs at an early stage of oxidative stress, so that they function as circuit breakers, halting the production of damaging superoxide radicals by temporarily shutting down oxidative metabolism (Gardner \& Fridovich, 1991, 1992). Once the stress has passed, the (de)hydratases can be reactivated by intracellular $\mathrm{Fe}^{2+}$ and thiols, rather than having to be synthesized de novo.

The aim of the present work was to construct an acn $A$ mutant of E. coli, by replacing the wild-type chromosomal gene with an in vitro-inactivated $\operatorname{acn} A$ gene, in order to investigate the $\mathrm{Acn}^{-}$phenotype and to study the regulation of AcnA synthesis using an acn A-lac $Z$ gene fusion. This revealed a residual aconitase activity, designated AcnB. It was found that $\operatorname{acn} A$ resembles other citric acid cycle genes in being subject to CRP-mediated catabolite repression and ArcA-mediated anaerobic repression, and that it is positively regulated by the ferric uptake regulator (Fur), which normally functions as a repressor, and by the oxidative stress regulatory system (SoxRS).

\section{METHODS}

Bacterial strains, plasmids, phagemids and bacteriophages. The strains of Escherichia coli K12, with relevant genotypes and sources, are listed in Table 1. The phagemid containing the intact acn $A$ gene, pGS447 (Fig. 1), had been assembled previously by ligating a $3.2 \mathrm{~kb} \mathrm{Bam} \mathrm{HI} \mathrm{fragment} \mathrm{and} \mathrm{a} 1.02 \mathrm{~kb}$ BamHI-Pst fragment in pUC119 (Prodromou et al., 1991). The source of the $1.3 \mathrm{~kb} \mathrm{~N} c o \mathrm{I}-\mathrm{Sall}_{\mathrm{I}}$ fragment containing the kan ${ }^{\mathrm{R}}$ cassette was PMTL24-Kan, which was constructed by inserting PstI-treated $\mathrm{Km}^{\mathrm{R}}$ GenBlock (Pharmacia) into the multicloning site of pMTL24 (Chambers et al., 1988), in order to provide the flanking $N_{c o I}$ and $S a l I$ sites. Other plasmids are shown in Table 1 or Fig. 1.

The acn $A-l a c Z$ translational fusion was created by ligating the $1.6 \mathrm{~kb} \mathrm{BamHI}-$ Sall fragment containing parts of the $c y s B-a c n A$ intergenic and acn $A$ coding regions into pNM482 to generate pGS563 (Fig. 1). The fusion was then transferred to $\lambda$ RZ5 (M. Berman) by in vivo recombination in strain RK4353(pGS563) according to Spiro \& Guest (1987). The corresponding $\lambda$ acn $A$-lac $Z$ fusion phage ( $\lambda G 244$ ) was established as a single-copy prophage in different sets of host strains for investigating the roles of global regulators in acn $A$ expression. Lysogens were selected initially with $\lambda b 80 \mathrm{de} l 9 \mathrm{c}$ and monolysogens were identified by their sensitivity to $\lambda c I 90 c 17$. Each set of גacn A-lac Z monolysogens consisted of a parental strain, a regulator mutant, and the mutant containing a multicopy plasmid expressing the wild-type regulator gene, respectively for the following regulators: CRP [MC1000, JRG1999, and JRG1999(pGS279)]; ArcA [MC4100, BW3218, and BW3218(pRB38)]; FNR [RK4353, RK5279, and RK5279(pCH21)]; and Fur [MC4100, H1941, and H1941(pMH15)]; see Table 1. Analogous $\lambda f u m-l a c Z$ monolysogens were isolated with the Fur set of hosts using the fusion phages described previously by Woods \& Guest (1987): $\lambda$ G185 ( $\lambda$ fum A-lacZ); $\lambda \mathrm{G} 186$ ( $\lambda$ fumB-lacZ); and $\lambda \mathrm{G} 187$ ( $\lambda$ fumC-lacZ); see Fig. 1. In the case of the SoxRS regulator, גacn $A-l a c Z$ and $\lambda f u m-l a c Z$ monolysogens were only made with the correspond- ing parental (GC4468) and soxR mutant (DJ901) hosts (Table 1).

Media and growth tests. The complex media were $\mathrm{L}$ broth for routine subculture and peptone broth for specific growth tests (Guest, 1981), supplemented as required with ampicillin $\left(100 \mu \mathrm{g} \mathrm{m}^{-1}\right)$, chloramphenicol $\left(25 \mu \mathrm{g} \mathrm{ml}^{-1}\right)$, kanamycin $\left(15 \mu \mathrm{g} \mathrm{m}^{-1}\right)$ and glucose $(50 \mathrm{mM})$. The citrate-free minimal medium (Cole \& Guest, 1980) was used with glucose (20 mM), sodium acetate $(40 \mathrm{mM})$, sodium succinate $(40 \mathrm{mM})$, sodium DL-lactate $(40 \mathrm{mM})$ or sodium pyruvate $(40 \mathrm{mM})$ as carbon sources, and supplements of thiamin hydrochloride $\left(5 \mu \mathrm{g} \mathrm{ml}^{-1}\right)$ and L-glutamate $(2 \mathrm{mM})$ or L-proline $(0.22 \mathrm{mM})$, as required. Cultures $(10 \mathrm{ml})$ were grown at $37^{\circ} \mathrm{C}$, either aerobically in shaking $250 \mathrm{ml}$ conical flasks or anaerobically in stationary tubes filled to the neck. Inocula were prepared from stationaryphase cultures grown in the same medium (with appropriate antibiotics), washed in saline, and added to give a starting $\mathrm{OD}_{650}$ of $0 \cdot 1$.

Enzymology. For assaying aconitase, cultures $(1.5 \mathrm{ml})$ were harvested in early stationary phase, resuspended at $0{ }^{\circ} \mathrm{C}$ in $300 \mu \mathrm{l}$ Tris/citrate buffer $(20 \mathrm{mM}, \mathrm{pH} 8 \cdot 0)$, and disrupted by two ultrasonic treatments of $10 \mathrm{~s}$ at $10 \mathrm{MHz}$ separated by a $30 \mathrm{~s}$ interval. Cell debris was removed by centrifuging $(10000 \mathrm{~g}$,

\section{Table 1. E. coli strains and plasmids}

\begin{tabular}{|c|c|c|}
\hline $\begin{array}{l}\text { Strain or } \\
\text { plasmid }\end{array}$ & $\begin{array}{c}\text { Relevant } \\
\text { characteristics }\end{array}$ & $\begin{array}{l}\text { Source or } \\
\text { reference* }\end{array}$ \\
\hline W3110 & Prototroph & Laboratory collection \\
\hline JRG2789 & $\begin{array}{l}\text { acn } A:: k_{a n}^{R} \text { derivative of } \\
\text { W } 3110\end{array}$ & This work \\
\hline $\mathrm{DH} 5 \alpha$ & $\begin{array}{l}\Delta\left(\operatorname{argF}-l_{a c}\right) \mathrm{U} 169 \\
\quad(\phi 80 \Delta l a c Z M 15) \operatorname{rec} A\end{array}$ & $\begin{array}{l}\text { Sambrook et al. } \\
\text { (1989) }\end{array}$ \\
\hline MC1000 & $\Delta l a c$ X74 $\Delta(\operatorname{ara} A B C-l e u)$ & Silhavy et al. (1984) \\
\hline JRG1999 & $\mathrm{MC} 1000 \Delta c r p \mathrm{~T} 8$ & S. T. Cole ${ }^{1}$ \\
\hline BW3218 & $\begin{array}{l}\Delta(\arg F-l a c) \mathrm{U} 169 \\
\Delta(\operatorname{ser} B-\operatorname{arc} A-t b r)\end{array}$ & R. Buxton ${ }^{2}$ \\
\hline RK4353 & $\Delta(\arg F-l a c) \mathrm{U} 169$ & V. Stewart ${ }^{3}$ \\
\hline RK5279 & $\mathrm{RK} 4353$ fnr -250 & V. Stewart \\
\hline MC4100 & $\Delta(\arg F-l a c) \mathrm{U} 169 r p s L$ & Silhavy et al. (1984) \\
\hline H1941 & MC4100 $\Delta f u r$ & K. Hantke $\mathrm{e}^{4}$ \\
\hline GC4468 & $\Delta(\arg F-l a c) \mathrm{U} 169 r p s L$ sup & $\begin{array}{l}\text { Greenberg et al. } \\
(1990)\end{array}$ \\
\hline DJ901 & GC4468 $\Delta s o x R$ & $\begin{array}{l}\text { Greenberg et al. } \\
(1990)\end{array}$ \\
\hline pMAK705 & $\mathrm{Rep}_{\mathrm{ts}}, \mathrm{Cm}^{\mathrm{R}}$ & $\begin{array}{l}\text { Hamilton et al. } \\
\text { (1989) }\end{array}$ \\
\hline pGS526 & $\begin{array}{l}\mathrm{pMAK} 705 \text { acn } A:: k a n^{R} \\
\mathrm{Cm}^{\mathbf{R}}\end{array}$ & This work \\
\hline pNM482 & Gene fusion vector, $A p^{R}$ & Minton (1984) \\
\hline pGS563 & pNM482 acn $A-l a c Z, \mathrm{Ap}^{\mathrm{R}}$ & This work \\
\hline pGS279 & $c r p^{+}, \mathrm{Ap}^{\mathrm{R}} \mathrm{Cm}^{\mathrm{R}}$ & Spiro et al. (1989) \\
\hline $\mathrm{pCH} 21$ & $f n r^{+}, \mathrm{Ap}^{\mathrm{R}} \mathrm{Cm}^{\mathrm{R}}$ & C. Higgins ${ }^{5}$ \\
\hline pRB38 & $\operatorname{arc} A^{+}, \mathrm{Cm}^{\mathrm{R}}$ & R. Buxton \\
\hline pMH15 & $\mathrm{fur}^{+}, \mathrm{Cm}^{\mathrm{R}}$ & K. Hantke \\
\hline
\end{tabular}

* 1, Pasteur Institute, Paris, France; 2, National Institute for Medical Research, Mill Hill, London, UK; 3, Cornell University, Ithaca, NY, USA ; 4, University of Tübingen, Germany; 5, Imperial Cancer Research Fund, John Radcliffe Hospital, Oxford, UK. 
$5 \mathrm{~min}$ ) and the supernatants (cell-free extracts) were usually assayed immediately but could be stored for $2 \mathrm{~d}$ at $-20^{\circ} \mathrm{C}$. Aconitase was assayed spectrophotometrically at room temperature by following the formation of cis-aconitate from isocitrate at $240 \mathrm{~nm}$, using an absorption coefficient of $3.6 \mathrm{mM}^{-1}$, as described by Kennedy et al. (1983). One unit of activity (U) represents $1 \mu \mathrm{mol}$ cis-aconitate formed $\mathrm{min}^{-1}$. In some experiments isocitrate $(20 \mathrm{mM})$ was replaced by citrate $(20 \mathrm{mM})$ or $c i s$-aconitate $(0 \cdot 2 \mathrm{mM})$. Protein concentrations were determined by the Bio-Rad micro-assay procedure. In the reactivation studies, $100 \mu \mathrm{l}$ samples of cell-free extract were incubated at $0^{\circ} \mathrm{C}$ with $10 \mathrm{mM}$ dithiothreitol, $1.0 \mathrm{mM}$ $\mathrm{Fe}\left(\mathrm{NH}_{4}\right)_{2}\left(\mathrm{SO}_{4}\right)_{2}$ and $20 \mathrm{mM}$ Tris/ $\mathrm{HCl}, \mathrm{pH} 8 \cdot 0$, and then assayed at $10 \mathrm{~min}$ intervals.

$\beta$-Galactosidase activities were determined according to Miller (1972) using monolysogens containing lac $Z$ fusion phages (see above) grown to early stationary phase $\left(O D_{650}=1.2\right.$ for iacn $A$-lac $Z$ ) or late exponential phase $\left(\mathrm{OD}_{650}=0.8\right.$ for $\lambda$ fum-lac $Z$ ), in unsupplemented $\mathrm{L}$ broth or $\mathrm{L}$ broth containing glucose $(0.4$ or $1 \%)$. In experiments involving Fur, available iron was depleted by adding bipyridyl $(32 \mathrm{mM})$ at $\mathrm{OD}_{650}=0 \cdot 4$, and in the SoxRS studies, oxidative stress was imposed by adding methyl viologen $\left(0.2 \mathrm{mg} \mathrm{m}^{-1}\right) 1 \mathrm{~h}$ before sampling. Specific activities (Miller units) were averaged from at least three independent cultures, the variation between samples being $<10 \%$

Western blotting. PAGE was performed as described by Laemmli (1970) using denaturing conditions $(0 \cdot 1 \%$ SDS in all buffers and $15 \%, w / v$, acrylamide) and biotinylated size markers $\left(M_{\mathrm{r}}\right)$ : phosphorylase $b(97400)$; catalase $(58100)$; alcohol dehydrogenase (39800); carbonic anhydrase (29000). Samples in SDS-polyacrylamide gels were transferred to nitrocellulose with a Bio-Rad Transblot Electrophoretic Transfer Cell according to the manufacturer's instructions. The blots were immuno-stained using aconitase $A$ antiserum as the primary antiserum, biotinylated anti-rabbit antibodies and streptavidin-biotinylated horseradish peroxidase complex according to Prodromou et al. (1991).

DNA manipulation and Southern blotting. DNA was prepared and manipulated by standard procedures (Sambrook et al., 1989). For Southern blotting, endonuclease-digested bacterial DNA was fractionated by electrophoresis $(0 \cdot 8 \%$ agarose, Tris/acetate/EDTA gel) and transferred to nitrocellulose membrane (Sambrook et al., 1989). The blots were hybridized for $18 \mathrm{~h}$ at $68^{\circ} \mathrm{C}$ with $5 \times \mathrm{SSC}$ and washed $(2 \times 15 \mathrm{~min})$ with $0.1 \times \operatorname{SSC}$ plus $0 \cdot 1 \% \operatorname{SDS}(\mathrm{w} / \mathrm{v})$ at $65^{\circ} \mathrm{C}[1 \times \mathrm{SSC}$ contains $\mathrm{NaCl}(0 \cdot 15 \mathrm{M})$ and sodium citrate $(0 \cdot 015 \mathrm{M}, \mathrm{pH} 7 \cdot 0)]$. Digoxigenin-labelled probes containing the $1.3 \mathrm{~kb} \mathrm{kan}^{\mathrm{R}}$ cassette and the $1.6 \mathrm{~kb}$ SalI-Bam HI fragment of the acn $A$ coding region were derived from M13 templates by primer-extension labelling using universal primer and a non-radioactive DNA-labelling kit (Boehringer-Mannheim). The corresponding restriction fragments were isolated after electrophoresis in a low-meltingpoint agarose gel and used in hybridization and detection according to the manufacturer's instructions.

Materials. Isocitric acid, cis-aconitic acid and biotinylated molecular mass markers for SDS-PAGE were obtained from Sigma. Alkaline phosphatase, T4 DNA ligase and the NonRadioactive Digoxigenin Labelling Kit were from BoehringerMannheim. Biotinylated anti-rabbit antibody and the streptavidin-biotinylated horseradish peroxidase complex were from Amersham. Restriction enzymes were purchased from Northumbria Biologicals, Klenow DNA polymerase and the kanamycin resistance GenBlock were from Pharmacia, and Iniversal primer was from Cambridge Bioscience.

\section{RESULTS}

\section{Construction of an acnA mutant by gene replacement}

An $\operatorname{acn} A$ mutant was constructed by replacing the chromosomal acn $A$ gene of $E$. coli $\mathrm{W} 3110$ by an in vitrodisrupted gene designated acn $A:: k_{a n}{ }^{R}$, according to the method of Hamilton et al. (1989). The $1.04 \mathrm{~kb}$ SalI-NcoI segment of pGS447, encoding residues 122 to 460 (all of domain 2 and parts of domains 1 and 3; Prodromou et al., 1992), was first replaced by the corresponding $1.3 \mathrm{~kb} \mathrm{kan}{ }^{R}$ cassette of pMTL24-Kan, to produce pGS525 (Fig. 1). The entire acn $A:: \mathrm{kan}^{R}$ region was then ligated between the KpnI and SpbI sites in the polylinker of the thermosensitive replicon, pMAK 705, to generate pGS526. Some 25 plasmid cointegrates arising by homologous recombination between pGS526 and the chromosome were obtained by direct selection for $\mathrm{Cm}^{\mathbf{R}}$ and $\mathrm{Km}^{\mathrm{R}}$ transformants of W3110 at $42{ }^{\circ} \mathrm{C}$. This represented $0.5 \%$ of comparable transformants obtained at $30^{\circ} \mathrm{C}$. The cointegrates were streaked to single colonies and cultured to stationary phase at $30^{\circ} \mathrm{C}(5$ colonies per $100 \mathrm{ml}$ of $\mathrm{L}$ broth containing both antibiotics) to allow resolution by a second recombination event. The desired resolution products, in which the chromosomal acn $A$ gene had been replaced by the $\operatorname{acn} A:$ kan $^{R}$ construction,

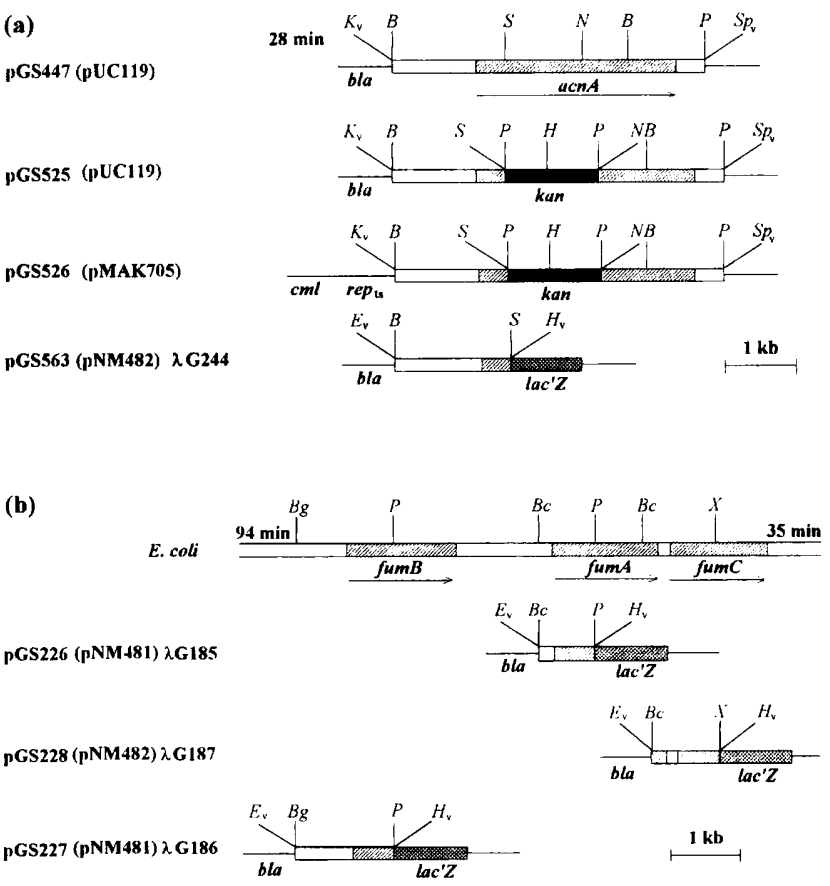

Fig. 1. Restriction maps of the acnA, fumAC and fumB regions showing segments cloned in specific plasmids, the strategy for acnA gene disruption by the $k a n^{R}$ cassette, and the construction of the corresponding acnA-lacZ and fum-lac $Z$ fusion phages. The polarity of the acnA gene (a) is clockwise in the $E$. coli chromosome, whereas the fum genes (b) are polarized anticlockwise. Relevant restriction sites are: $B$, BamHI; $B C, B C l$; $B g, B g / I I ; E, E c o R l ; H$, HindIII; K, Kpnl; N, Ncol; P, Pstl; S, Sall; Sp, Sphl; $X, X$ hol; the subscript $\left(_{v}\right)$ refers to flanking vector sites used in subcloning. 


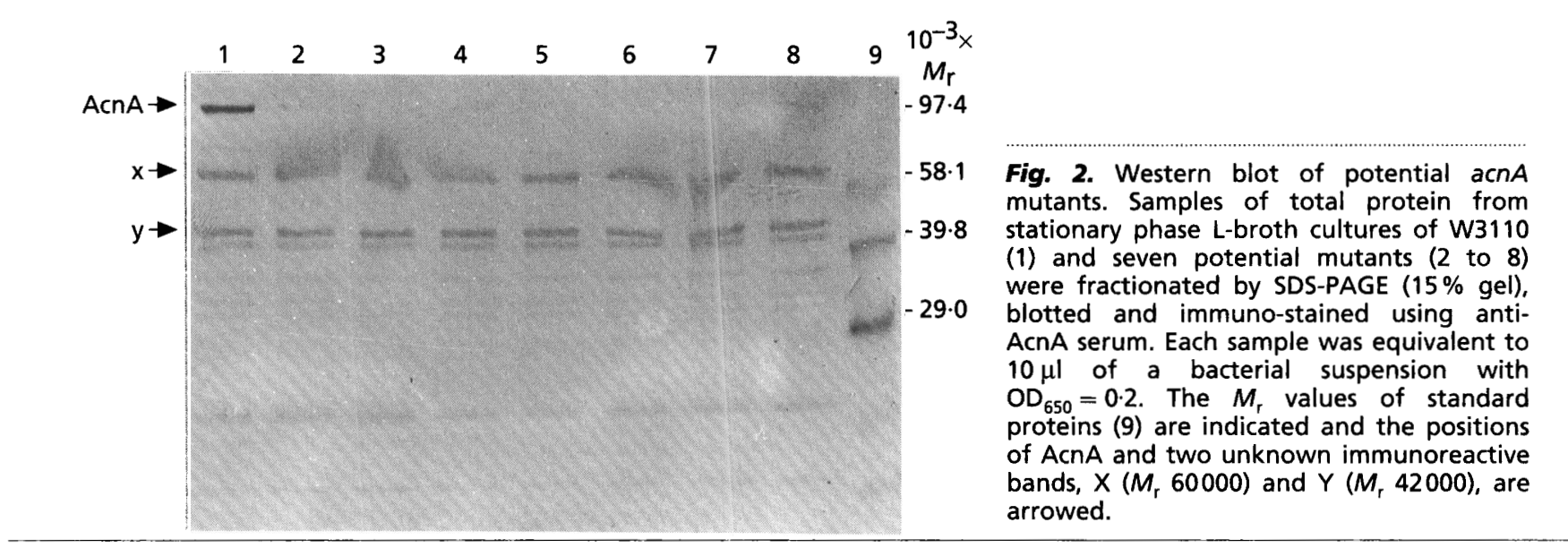

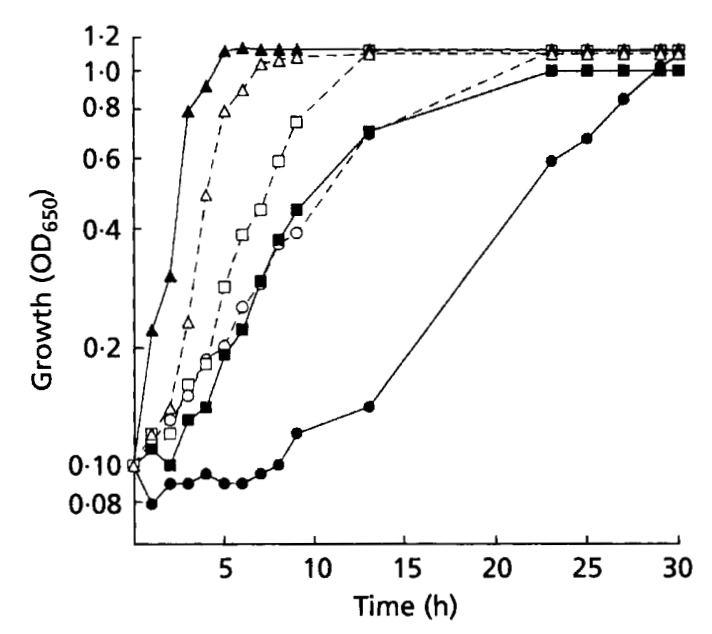

Fig. 3. Aerobic growth of acnA mutant and parental strains. Cultures of JRG2789 (acnA; broken lines and open symbols) and W3110 (acn $A^{+}$; unbroken lines and filled symbols) were grown at $37^{\circ} \mathrm{C}$ with shaking, in peptone medium $(\triangle, \Delta)$ or minimal media with acetate $(\square, \square)$ or succinate $(0,0)$ as substrates. Saline-washed suspensions of bacteria grown overnight in the same media (with kanamycin, $15 \mu \mathrm{g} \mathrm{ml}^{-1}$, for the mutant) were used as inocula for the $10 \mathrm{ml}$ cultures.

were obtained by selecting $\mathrm{Km}^{\mathrm{R}}$ colonies at $42^{\circ} \mathrm{C}$ and then screening for $\mathrm{Km}^{\mathrm{R}} \mathrm{Cm}^{\mathrm{s}}$ products at $30^{\circ} \mathrm{C}$. From a total of $125 \mathrm{Km}^{\mathbf{R}}$ colonies ( 25 per resolution culture), 22 had the desired phenotype and seven of these potential $\operatorname{acn} A:$ kan $^{R}$ mutants were chosen for further analysis.

Western blotting showed that all seven potential acn $A$ mutants lacked the immunoreactive polypeptide corresponding to $\operatorname{Acn} \mathrm{A}\left(M_{\mathrm{r}} 97500\right)$ in the parental strain (Fig. 2). Two additional immunoreactive polypeptides $\left(M_{\mathrm{r}}\right.$ 60000 and 42000) were detected in all samples, but it is not known whether they are related to aconitase or if they correspond to contaminants in the sample of aconitase used to raise the antiserum. Other positive bands present in all samples were due to non-specific binding by the secondary antibody.

Chromosomal DNA from a representative mutant (JRG2789) was also compared to that of the parent
(W3110) by Southern blotting with two hybridization probes under high-stringency conditions. The $1.6 \mathrm{~kb}$ Bam HI-SalI internal fragment of the acn $A$ gene was used as an acn $A$ probe and the kan ${ }^{R}$ cassette served as the kan probe. The fragments hybridizing to the acn $A$ probe were exactly as predicted for Bam HI, Pst I and Bam HI + HindIII digests of both W3110 DNA $(3 \cdot 2,9 \cdot 2$, and $3 \cdot 2 \mathrm{~kb}$, respectively) and JRG2789 DNA $(3 \cdot 5,1 \cdot 6$, and $1 \cdot 3 \mathrm{~kb})$, assuming that the desired replacement had been effected (Fig. 1). Likewise, the kan probe hybridized to fragments of $3 \cdot 5,1 \cdot 3$, and $1 \cdot 3+2 \cdot 1 \mathrm{~kb}$ in respective digests of mutant DNA, but failed to bind to any fragments in digests of parental DNA. These observations confirmed that the chromosomal acn $A^{+}$gene of W 3110 had been successfully replaced by the disrupted acn $A:$ : kan ${ }^{R}$ gene from pGS526 in the representative acn $A$ mutant, JRG2789.

\section{Nutritional characterization of the acnA mutant}

Citrate synthase ( $g l t A)$ and isocitrate dehydrogenase (icd) mutants have an absolute requirement for glutamate (or proline) during growth in glucose minimal medium and they cannot use acetate as sole carbon and energy source with or without supplementary glutamate (Lakshmi \& Helling, 1976). It was therefore assumed that an aconitase mutant would possess the same nutritional phenotype. However, aerobic and anaerobic growth tests in solid and liquid media showed that the acn $A$ mutants grew as well as the parental strain in unsupplemented glucose minimal medium. Added glutamate or proline produced a slight enhancement but this was the same for both the mutant and wild-type strains. The $\operatorname{acn} A$ mutation also had no significant effect on growth in lactate and pyruvate minimal media or in $\mathrm{L}$ broth (with or without glucose, $1 \% \mathrm{w} / \mathrm{v})$. However, the acn $A$ mutation reproducibly increased the lag phase during growth in peptone medium, decreased the lag phase in succinate minimal medium, and led to a slightly higher growth yield in acetate minimal medium (Fig. 3).

\section{Enzymological characterization of the acnA mutant}

Enzymological tests showed that the acn $A$ mutants retained aconitase activity. The activities obtained, when assayed with citrate, cis-aconitate, and isocitrate as 
Table 2. Aconitase activities of mutant and parental strains

Freshly prepared ultrasonic extracts of strains grown to early stationary phase in $\mathrm{L}$ broth were assayed without reactivation. One unit of aconitase activity corresponds to the formation or transformation of $1 \mu \mathrm{mol}$ cis-aconitate $\min ^{-1}$. The results are means of triplicate assays with at least three independent extracts, \pm SE.

\begin{tabular}{|c|c|c|}
\hline \multirow[t]{2}{*}{ Substrate } & \multicolumn{2}{|c|}{$\begin{array}{c}\text { Aconitase specific activity } \\
{\left[\mathrm{U}(\mathrm{mg} \text { protein })^{-1}\right]}\end{array}$} \\
\hline & $\begin{array}{c}\mathrm{W} 3110 \\
\left(\operatorname{acn} A^{+}\right)\end{array}$ & $\begin{array}{c}\text { JRG2789 } \\
\left(a c n A:: \text { Ran }^{R}\right)\end{array}$ \\
\hline $\begin{array}{l}\text { Isocitrate } \\
\text { iis-Aconitate } \\
\text { Citrate }\end{array}$ & $\begin{array}{l}0 \cdot 18 \pm 0 \cdot 02 \\
0 \cdot 17 \pm 0 \cdot 02 \\
0 \cdot 10 \pm 0 \cdot 01\end{array}$ & $\begin{array}{l}0 \cdot 04 \pm 0 \cdot 02 \\
0 \cdot 03 \pm 0 \cdot 01 \\
0 \cdot 02 \pm 0 \cdot 01\end{array}$ \\
\hline
\end{tabular}

substrates, ranged from approximately 10 to $30 \%$ of the corresponding wild-type activities at stationary phase in L-broth cultures (Table 2). The aconitase specific activity in wild-type cultures increases during the exponential phase to reach a maximum at stationary phase (Prodromou et al., 1991). In contrast, the aconitase activity of the acn $A$ mutant reached a somewhat earlier maximum and then decreased during the stationary phase. The residual activity detected in the mutant may thus represent a higher proportion of the total activity of the wild-type during exponential phase.

The residual aconitase was unstable and resembled other aconitases in being reactivated by ferrous ions under reducing conditions. Thus the specific activity of a typical mutant extract declined steadily from 0.06 to $0.02 \mathrm{U}$ (mg protein $)^{-1}$ during incubation for a period of $40 \mathrm{~min}$ at $20{ }^{\circ} \mathrm{C}$, but then increased to $0.09 \mathrm{U}$ (mg protein $)^{-1}$ when incubated at $0^{\circ} \mathrm{C}$ for $60 \mathrm{~min}$ in the presence of dithiothreitol (DTT, $1 \mathrm{mM})$ and $\mathrm{Fe}^{2+}(10 \mathrm{mM})$.

These observations show that in addition to AcnA there is at least one other analogous but genetically distinct aconitase in $E$. coli. This residual enzyme activity, designated $A \operatorname{cn} B$, is assumed to be the product of a putative $a c n B$ gene, although the existence of more than one additional acn gene has not been excluded.

\section{Regulation of aconitase synthesis}

The residual aconitase activity $(A c n B)$ of the acn $A$ mutant was compared to the total activity (AcnA plus $A c n B$ ) of the parental strain, after growth in different media and with different carbon sources (Table 3 ). The AcnB activity was relatively constant in cultures grown in rich media, whereas total aconitase activity was significantly repressed by glucose and anaerobiosis. This indicates that $\operatorname{Acn} A$ synthesis is subject to catabolite and anaerobic repression and that $A c n B$ synthesis is differently regulated. The aconitase activities of both mutant and parental cultures observed after growth in minimal media were similar with

\section{Table 3. Effects of growth medium on aconitase synthesis}

Aconitase specific activities, $\mathrm{U}$ (mg protein $)^{-1}$, were assayed in ultrasonic extracts of duplicate early stationary phase cultures, grown aerobically unless stated otherwise. $\beta$-Galactosidase expressed from the single-copy $\lambda a c n A-l a c Z$ prophage was also assayed in early stationary phase and the specific activities (Miller units) were averaged from triplicate cultures. The variation between replicate samples was less than $15 \%$ for both enzymes.

\begin{tabular}{|c|c|c|c|}
\hline \multirow[t]{2}{*}{ Medium } & \multicolumn{2}{|c|}{ Aconitase } & \multirow{2}{*}{ 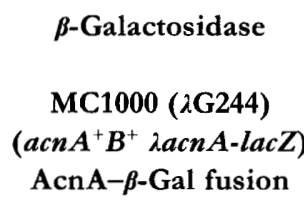 } \\
\hline & $\begin{array}{c}W 3110 \\
\left(\operatorname{acn} A^{+} a c n B^{+}\right) \\
A c n A+A c n B\end{array}$ & $\begin{array}{c}\text { JRG2789 } \\
\left(\operatorname{acn} A:: \operatorname{kan}^{R} a c n B^{+}\right) \\
\operatorname{AcnB}\end{array}$ & \\
\hline L broth & $0 \cdot 20$ & $0 \cdot 04$ & $30-50$ \\
\hline L broth + glucose & $0 \cdot 10$ & 0.03 & 13 \\
\hline L broth (anaerobic) & 0.08 & 0.03 & 2 \\
\hline $\begin{array}{l}\mathrm{L} \text { broth }+ \text { glucose } \\
\text { (anaerobic) }\end{array}$ & $0 \cdot 05$ & 0.03 & 3 \\
\hline Peptone broth & $0 \cdot 18$ & 0.03 & 23 \\
\hline Glucose minimal & 0.02 & 0.01 & $1 \cdot 5$ \\
\hline $\begin{array}{l}\text { Glucose minimal } \\
\text { (anaerobic) }\end{array}$ & 0.02 & $0 \cdot 01$ & 1 \\
\hline Lactate minimal & 0.05 & 0.06 & 7 \\
\hline Pyruvate minimal & $0 \cdot 02$ & 0.02 & 7 \\
\hline Acetate minimal & 0.03 & 0.03 & 9 \\
\hline Succinate minimal & 0.05 & 0.06 & 10 \\
\hline
\end{tabular}



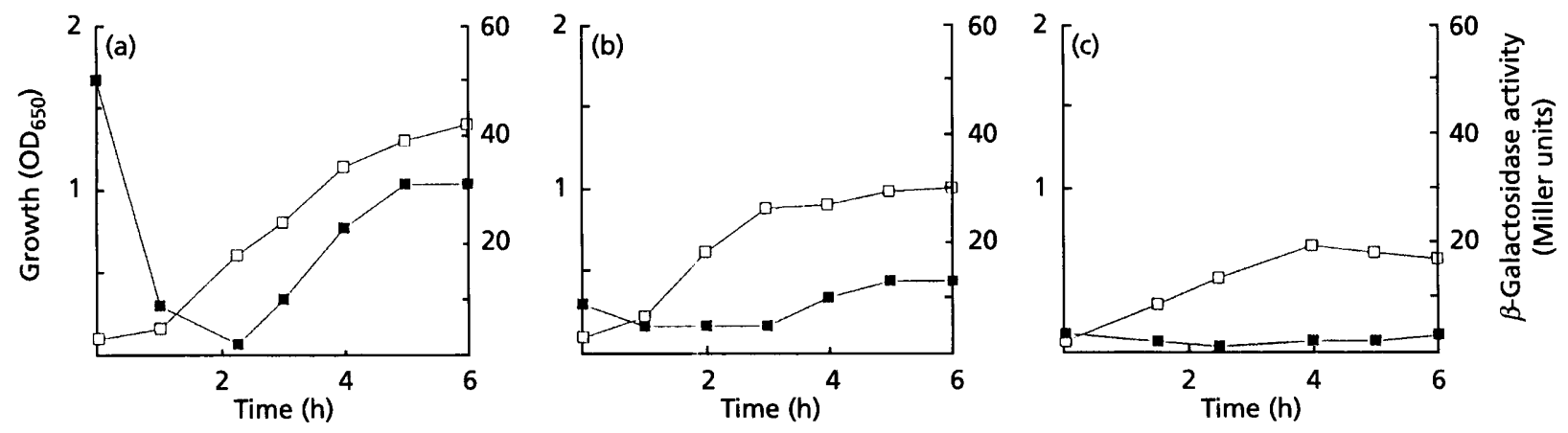

Fig. 4. Effects of glucose and anaerobiosis on the expression of a single-copy acnA-lacz fusion during the growth cycle. Growth $\left(\square ; O D_{650}\right.$ ) and $\beta$-galactosidase specific activities ( $\square$; Miller units; averaged from at least three independent cultures) were monitored for cultures grown at $37^{\circ} \mathrm{C}$ in: a, aerobic L broth; b, aerobic L broth plus glucose (0.4\%); and $\mathrm{c}$, anaerobic $L$ broth plus glucose $(0.4 \%)$.
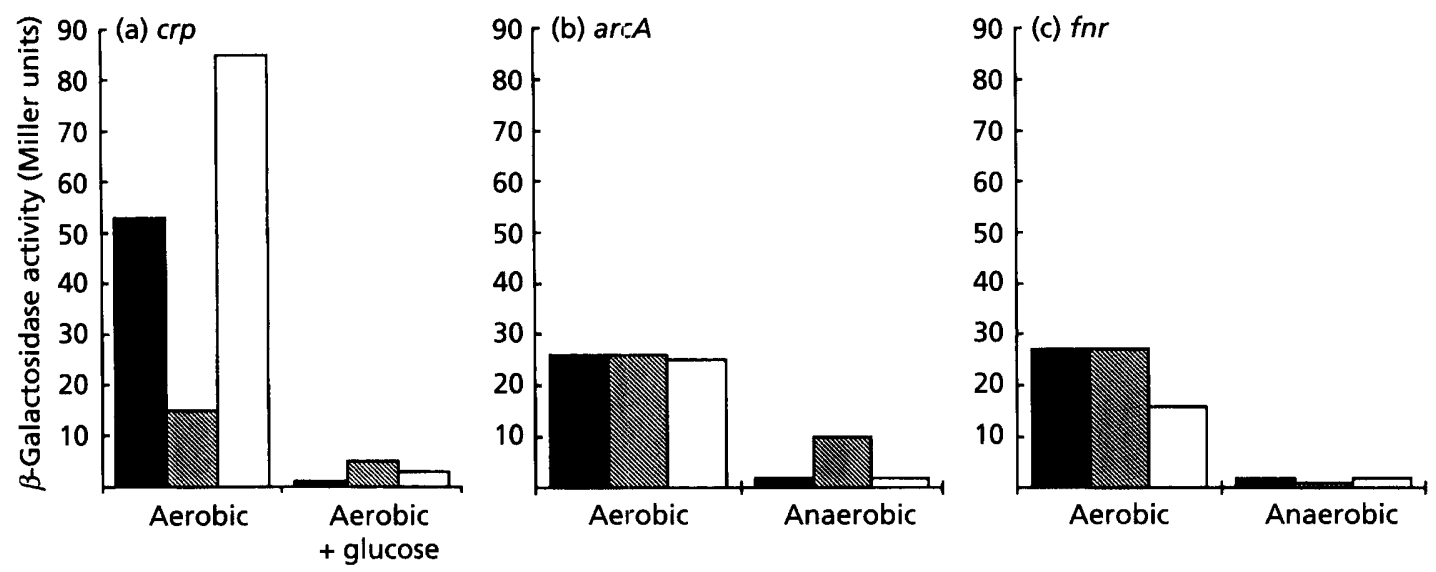

Fig. 5. Effects of CRP, ArCA and FNR on acnA-lacZ expression. $\beta$-Galactosidase specific activities of stationary-phase cultures of strains containing a $\lambda a c n A-l a c Z$ fusion prophage ( $\lambda G 244)$ were assayed after aerobic and anaerobic growth in $L$ broth (containing $1 \%$ glucose, where indicated). Monolysogenic derivatives of strains containing wild-type ( $\square$ ), mutant

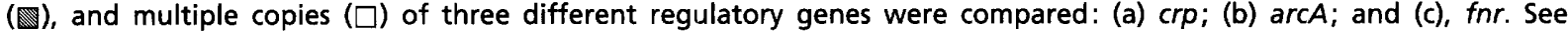
Methods for details of individual strains.

all substrates. This could mean that AcnA synthesis is repressed during growth in relatively poor media, leaving $\mathrm{Acn} B$ as the sole source of aconitase activity. It can also be concluded that $A \operatorname{cn} B$ is operational in both the glyoxylate and citric acid cycles because the mutant can use acetate as a sole carbon and energy source and acetate-grown cultures contain aconitase.

In order to study the regulation of AcnA synthesis in the presence of $A \mathrm{cnB}$, a $\lambda$ acn $A$-lac $Z$ fusion phage ( 2244 ), containing the acn $A$ promoter region and part of the acn $A$ structural gene linked 'in-phase' to a $\beta$-galactosidase reporter gene, was constructed and established as a singlecopy prophage in MC1000 (acn $\left.A^{+} B^{+} \Delta l a c\right)$. Studies with $\mathrm{L}$-broth cultures of $\mathrm{MC1000}(\lambda \mathrm{G} 244)$ showed that the $\beta$ galactosidase activity increases during the growth cycle: to a maximum in stationary phase (Fig. 4a), is repressed by glucose (Fig. 4b) and further repressed by anaerobiosis (Fig. 4c). Assuming that $\beta$-galactosidase activity truly reflects AcnA synthesis, it would appear that $\operatorname{acn} A$ is a typical citric acid cycle gene, subject to catabolite and anaerobic repression mediated by the corresponding regulators, CRP and ArcA. The effects of growth substrate on acn $A-l a c Z$ expression in minimal media are likewise consistent with the repression of Acn A synthesis under anaerobic conditions and on poorer substrates (Table 3). Further studies on the effects of global regulators on acn $A$ gene expression were made with a series of $\lambda \mathrm{G} 244$ monolysogens, acn $A^{+} B^{+} \Delta l a c$ ( acn $A-$ lac $Z$ ), each lacking a regulator or containing multiple copies of the corresponding gene.

\section{Regulation of acnA gene expression by CRP, ArcA and FNR}

The $\beta$-galactosidase activity expressed from a single-copy $\lambda a c n A-l a c Z$ fusion prophage in the $c r p^{+}$parental strain was reduced $3 \cdot 5$-fold in the $c r p$ deletion strain but restored by the presence of a multicopy $c r p^{+}$plasmid (Fig. 5a). The activities of the $c r p^{+}$strains were also much reduced by the 

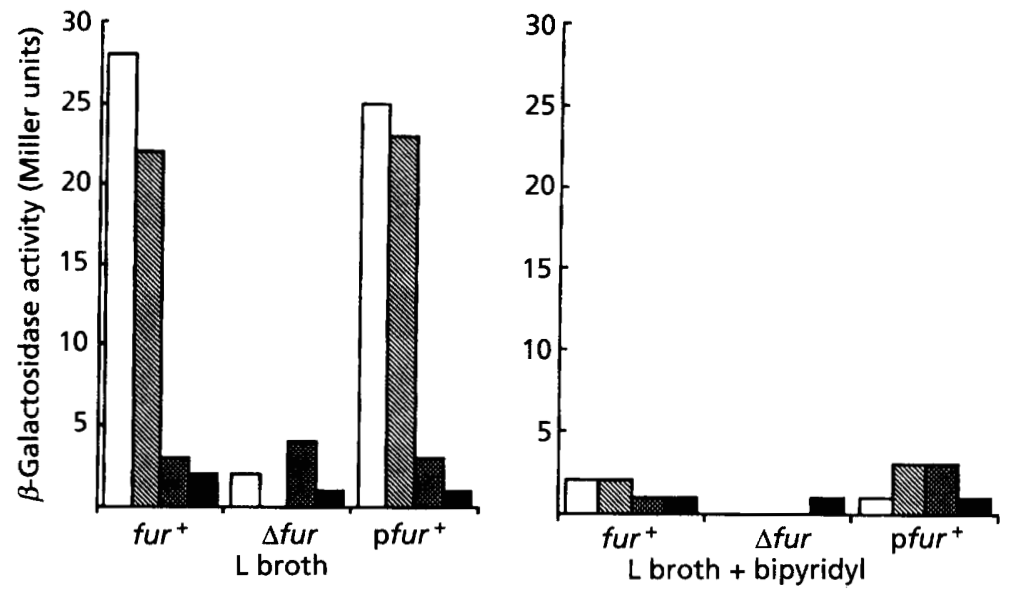

\begin{abstract}
Fig. 6. Effects of iron-depletion and Fur status on the expression of single-copy acnA-, fumA-, fumB- and fumC-lacZ fusions. The $\beta$-galactosidase specific activities were assayed after aerobic growth in L broth or L broth to which the ferrousion chelator bipyridyl ( $32 \mathrm{mM}$ ) was added at $\mathrm{OD}_{650}=0.4$ (see Methods). Derivatives of the parental strain (fur $r^{+} \Delta / a c$ ), the fur mutant ( $\Delta$ fur) and the mutant transformed with a multicopy fur ${ }^{+}$plasmid ( $p$ fur $r^{+}$) contained single copies of the following fusion

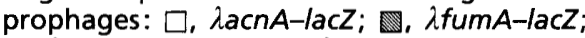
娄, ifumB-lacZ; and $\mathbf{\square}, \lambda$ fumC-lacZ.
\end{abstract}

addition of glucose $(1 \%)$. Thus it was concluded that the cAMP-CRP complex is required to activate transcription of the ain $A$ gene. This is consistent with the presence of potential CRP binding sites in the acn $A$ promoter region (Prodromou et al., 1992). Analogous studies on the role of ArcA showed that deletion of the $\operatorname{arc} A$ gene or the presence of an $\operatorname{arc} A^{+}$multicopy plasmid had no significant effect on acn $A$-lac $Z$ expression under aerobic conditions (Fig. 5b). In contrast, expression of the fusion was repressed 13-fold under anaerobic conditions in the parental and multicopy arc $A^{+}$strains, but only $2 \cdot 6$-fold for the $\operatorname{arc} A$ deletion strain. This indicates that ArcA probably functions as an anaerobic repressor of acn $A$ transcription. However, the fact that anaerobic repression was not totally abolished in the $\operatorname{arc} A$-deletion strain suggests that some other mechanism of anaerobic repression may be operating. Because this could involve FNR, the effects of $f n r$ mutation and multiple copies of the $\mathrm{fnr}^{+}$gene on acn $A-$-lac $Z$ expression were investigated (Fig. 5c). The results indicated that FNR is not directly responsible for the residual anaerobic repression, although it could still act in conjunction with ArcA, or function as an anaerobic repressor solely in the absence of ArcA. Such effects, and also the partial repression observed with multicopy $\mathrm{fnr}^{+}$under aerobic conditions (Fig. 5c), could be mediated via potential FNR sites in the acn $A$ promoter region (Prodromou et al., 1992).

\section{Regulation of the acnA and fum gene expression by Fur}

A role for the ferric uptake regulator (Fur) in acn $A$ gene expression was investigated partly because there are two potential Fur binding sites in the acn $A$ promoter region (Prodromou et al., 1992) and because AcnA contains an iron-sulphur centre which might render its synthesis responsive to iron availability. The $\beta$-galactosidase activities observed with cultures of $\lambda a c n A-l a c Z$ monolysogens grown in $\mathrm{L}$ broth with and without the iron chelator bipyridyl (Fig. 6) showed that iron and an active fur gene product are essential for good expression of the acn $A$ gene, and that the deleterious effects of a fur deletion were reversed by the presence of a multicopy fur $^{+}$plasmid. It would therefore appear that Fur serves as a transcriptional activator of acn $A$ gene expression, although the existence of an indirect mechanism of Fur-mediated activation was not excluded.

These studies were extended to include the three fumarase genes of $E$. coli because the fum $A$ and fum $B$ genes encode analogous oxygen-labile enzymes (FumA and FumB) resembling aconitase in possessing [4Fe-4S] clusters, whereas the fum $C$ gene encodes a stable tetrameric enzyme (FumC) resembling the mitochondrial fumarases (Miles \& Guest, 1984; Woods et al., 1986; Bell et al., 1989; Flint et al., 1992). Previous studies with a set of $\lambda$ fum-lac $Z$ fusion phages indicated that FumA is an aerobic citric acid cycle enzyme, the corresponding fum $A$ gene being subject to catabolite repression (CRP-mediated activation) and ArcA-mediated anaerobic repression, whereas FumB is expressed anaerobically from the catabolite- and ArcAinsensitive but FNR-activated fumB gene (Woods \& Guest, 1987; Guest \& Russell, 1992). Expression of the fum $C$ gene is not significantly affected by catabolite or anaerobic repression. However, it has recently been assigned to the soxRS regulon because FumC activity is strongly induced by oxidative stress but not in a strain lacking the SoxRS response (Liochev \& Fridovich, 1992). Using the same set of $\lambda$ fum-lac $Z$ fusion phages, the effects of iron-depletion, fur deletion and $\mathrm{fur}^{+}$gene amplification (Fig. 6) showed that as in the case of $\operatorname{acn} A$, expression of the fum $A$ gene requires iron and is activated by Fur. In contrast, fum $C$ expression was not significantly affected by iron depletion or Fur status (Fig. 6). There was some indication that fum $B$ expression might be iron-dependent and Fur-independent, but these tests were not done under anaerobic conditions where $f u m B$ is more highly expressed.

\section{Regulation of the acn $A$ and fum gene expression by SoxRS}

The soxRS oxidative stress regulon responds to superoxide-generating agents such as methyl viologen, by a two-stage process in which the SoxR protein is thought 

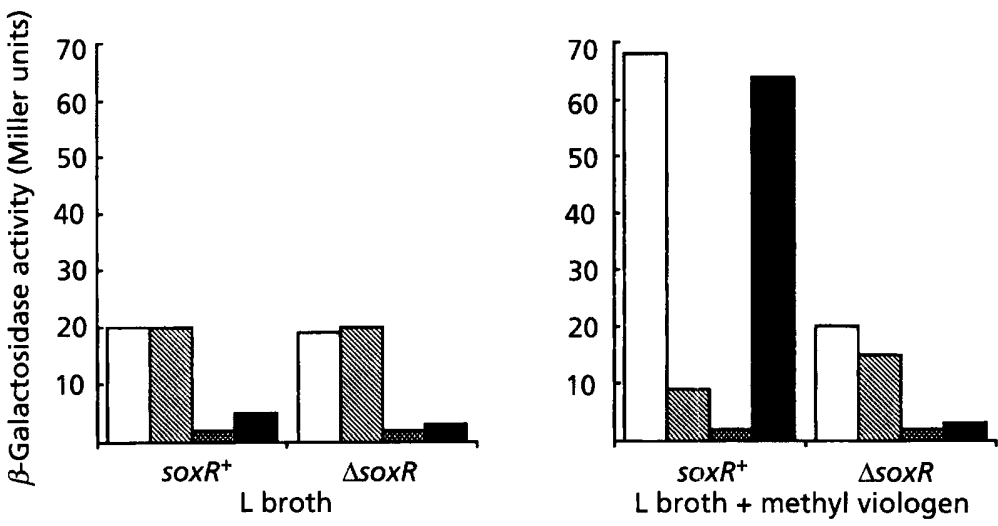

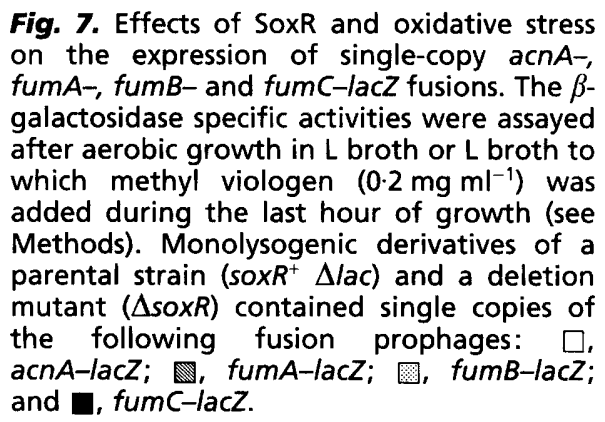

to serve as a redox-sensing activator of the adjacent so.xS gene, followed in turn by the activation of regulon genes by the SoxS protein (Amabile-Cuevas \& Demple, 1991; Hildago \& Demple, 1994). Studies with 2acnA--lacZ monolysogens of sox $\mathrm{R}^{+}$and $\Delta \operatorname{sox} \mathrm{R}$ strains indicated that the acn $A$ gene belongs to the sox $R S$ regulon, because $\beta$-galactosidase activities increased about three-fold with methyl viologen and this increase was entirely dependent on the presence of the wild-type soxR gene (Fig. 7). Direct assays for the effects of methyl viologen on the aconitase specific activity in extracts of L-broth cultures of W3110 $\left(a c n A^{+} a c n B^{+}\right)$and JRG2789 $\left(a c n A^{-} a c n B^{+}\right)$indicated that the total activity in the parental strain increased slightly $\left.[0 \cdot 18 \text { to } 0.22 \mathrm{U} \text { (mg protein })^{-1}\right]$ whereas that of the mutant decreased consistently $[0.03 \text { to } 0.01 \mathrm{U} \text { (mg protein })^{-1}$ ] under oxidative stress. If it is assumed that both enzymes are susceptible to oxidative disruption of their iron-sulphur centres, the apparent stability of the aconitase activity in W3110 (mainly AcnA) could be due to a compensatory increase in enzyme synthesis mediated by the SoxS-activation of the acn $A$ promoter under oxidative stress conditions, as observed with the corresponding acn $A-l a c Z$ fusion. Similar experiments with monolysogens containing $\lambda f u m-l a c Z$ fusion prophages confirmed that fum $C$, the gene encoding the oxygen-stable fumarase, is a member of the sox $\mathrm{R} S$ regulon. In the parental strain, expression from the fum $C-l a c Z$ fusion increased 13-fold with methyl viologen, but the superoxide generator had no effect in the soxR-deletion strain, indicating that fumC is normally positively activated by the SoxRS system (Fig. 7). In contrast, the fum $A$ and fum $B$ genes encoding the oxygen-labile iron-sulphur containing fumarases appeared not to belong to the sox $R S$ regulon because no sox $\mathrm{R}$-dependent induction by methyl viologen was observed (although some potential effects may be masked by the aerobic repression of $f u m B$ ).

\section{DISCUSSION}

The immunological and DNA hybridization properties of JRG2789 $\left(\operatorname{acn} A:: k a n^{R}\right)$ confirmed that the strategy for inactivating the chromosomal acn $A^{+}$gene had been successfully applied, despite the presence of residual aconitase activity and the lack of the anticipated glutamate auxotrophy. It is extremely unlikely that the product of the mutated acn $A$ gene retains aconitase activity because $38 \%$ of the structural gene (including codons for 10 out of 20 active-site residues) is replaced by the $k a n^{R}$ cassette. It would therefore appear that E. coli contains at least two aconitases (AcnA and $A(n B)$, and this may explain why mutants lacking aconitase have never been detected amongst glutamate auxotrophs or acetate-non-utilizing mutants. In view of their instability and reactivation by ferrous ions under reducing conditions, both enzymes seem to be analogous iron-sulphur proteins. However, unlike the iron-sulphur-containing fumarases, FumA and FumB, they do not appear to perform specific roles in aerobic and anaerobic metabolism. Nevertheless, some underlying functional specialization, based on the differential regulation of the acn $A$ and $a c n B$ genes, was indicated by the relative aconitase activities of mutant and parental strains grown under different conditions. The AcnB activity was relatively constant, whereas the deduced AcnA activity was repressed by glucose, anaerobiosis, and after growth in minimal media. The overall response to glucose and anaerobiosis is consistent with the earlier findings with wild-type strains (Gray et al., 1966; Iuchi \& Lin, 1988). The low activities with lactate, pyruvate, acetate and succinate were unexpected because E. coli should be more dependent on the citric acid cycle during growth with these substrates. Under most conditions the mutant and wild-type grew equally well, indicating that the two enzymes are functionally overlapping. However, with acetate and succinate as sole carbon sources the acn $A$ mutant grew better than the wild-type. The reason for this is obscure, but it could indicate that adapting to the use of $A \operatorname{cn} B$ is delayed in wild-type bacteria, and that $A \mathrm{cnB}$ is used preferentially in the glyoxylate cycle. The possibility that the residual aconitase activity (AcnB) in the $\operatorname{acn} A$ mutant is due to some other hydratase-dehydratase having a broad substrate specificity that includes citrate, cis-aconitate and isocitrate, has not been excluded.

In E. coli there is now evidence that at least four of the eight steps in the citric acid cycle are catalysed by 
genetically-distinct isoenzymes, including the aconitase reaction. The existence of analogous membrane-bound flavoprotein complexes (succinate dehydrogenase and fumarate reductase) catalysing the aerobic and anaerobic interconversion of fumarate and succinate is well known (Guest \& Russell, 1992). Likewise for the interconversion of fumarate and malate, there are closely-related aerobic and anaerobic fumarases (FumA and FumB) in addition to an unrelated mitochondrial type of fumarase (FumC), which is expressed during aerobic and anaerobic growth but specifically induced by oxidative stress (Woods $e t$ al., 1988; Woods \& Guest, 1987; Liochev \& Fridovich, 1992). More recently, a second form of citrate synthase has been isolated from a revertant of a glt $A$ mutant lacking the hexameric citrate synthase typically found in Gram-negative bacteria (Patton et al., 1993). The second enzyme closely resembles the citrate synthases of Grampositive bacteria and eukaryotes, and is presumably expressed from a reactivated cryptic gene. In some cases it is clear how enzyme duplication has provided opportunities for functional specialization and the acquisition of independent mechanisms regulating their expression. Such a process offers considerable advantages over the constitutive expression of a single all-purpose enzyme. In contrast, the lipoamide dehydrogenase component of the pyruvate and 2-oxoglutarate dehydrogenase complexes and the glycine cleavage system of E. coli is the product of a single gene (lpd). Despite the need for coexpression with three independently-regulated complexes, it would appear that there has not been sufficient need for functional specialization to promote gene or enzyme duplication (Guest et al., 1989) even though a second lipoamide dehydrogenase of uncertain function has been detected (Richarme, 1989). Isoenzymes likewise occur in the glycolytic pathway of E. coli, where different classes of fructose-1,6-bisphosphate aldolase may function preferentially in glycolysis or gluconeogensis, and two related glyceraldehyde-3-phosphate dehydrogenase genes have been found, one of which may be cryptic (Perham, 1990). The presence of two classes of fumarase and two citrate synthases has been demonstrated in Bacillus (Reaney et al., 1993; Jin \& Sonenshein., 1994). Mammalian tissues contain distinct cytoplasmic and mitochondrial aconitases, and the cytoplasmic enzyme, which more closely resembles AcnA than the mitochondrial enzyme (53\% versus $29 \%$ identity), also functions as an iron-responsive translational regulator or iron regulatory factor (IRF) after disruption of its iron-sulphur centre (Klausner \& Rouault, 1993). No parallel regulatory function has yet been observed for either of the E. coli aconitases, nor is there any evidence for an unrelated stable class of aconitase analogous to FumC.

Further information about the function of $A c n A$ was obtained using a single-copy acn $A$-lac $Z$ fusion to study the roles of global regulators in acn $A$ expression. These confirmed that the ain $A$ gene resembles other citric acid cycle genes in being positively regulated by the CAMP-CRP complex and negatively regulated by ArcA. However, the retention of some anaerobic repression of acn $A$-lac $Z$ fusion activity after deleting $\operatorname{arc} A$ (Fig. 5) contrasts with the $2 \cdot 3$-fold anaerobic derepression of total aconitase activity observed previously with an $\operatorname{arc} A$ mutant (Iuchi \& Lin, 1988). This discrepancy may reflect changing contributions of AcnB to the total aconitase activity measured in the latter work. The residual anaerobic repression suggests that other regulators may either repress acn $A$ under anaerobic conditions (especially in the absence of ArcA) or activate $\operatorname{acn} A$ expression under aerobic conditions both in the presence and absence of ArcA. FNR appeared not to function as an independent anaerobic repressor, but it could serve as an anaerobic repressor in the absence of ArcA. In this context it may be relevant that several genes, including $\operatorname{sod} A$ (manganese superoxide dismutase), $s d h$ (succinate dehydrogenase), cyo (cytochrome o), cyd (cytochrome $d$ ) and $p f l$ (pyruvate formate lyase), are regulated by both FNR and ArcA, and this dual action has recently been ascribed to the activation of $\operatorname{arc} A$ transcription by FNR for $\operatorname{sod} A$, sdh, and $c y o$, but not for $c y d$ or $p f l$ (Compan \& Touati, 1994).

Fusion studies further indicated that acn $A$ and fum $A$ are subject to a Fur- and iron-dependent activation, and that $\operatorname{acn} A$ and $\operatorname{fum} C$ are activated by the SoxRS system in response to oxidative stress (superoxide generation). The involvement of Fur is potentially significant because it could provide a link between citric acid cycle activity and iron availability. It is also interesting because Fur normally acts as an iron-responsive transcriptional repressor (Bagg \& Nielands, 1987), although it has been reported to activate the iron-containing superoxide dismutase gene, sodB (Niederhoffer $e t$ al., 1990). The mode of Fur-mediated activation is unknown, but there are two potential Fur sites upstream of two putative acn $A$ promoter sequences in the 1004 bp cys $B$-acn $A$ intergenic region (Prodromou et al., 1992). In the case of fum $A$, the transcriptional start point has been defined and here the -10 and +1 regions are overlapped by a putative Fur site (coordinates 278-296; Miles \& Guest, 1984). This seems an unlikely site for transcriptional activation. However, further searches have revealed a putative converging promoter in the antisense strand of the fum $A$ coding region $(+1$ coordinate $369,10 \mathrm{bp}$ downstream of the initiation codon). This is likewise overlapped by potential Fur sites in the fum $A$ coding region (coordinates 363-381, 402-420, 405-423 and 408-426). If transcription from the 'antisense' promoter inhibits fum $A$ expression, differential effects of Fur on the two converging promoters could provide a mechanism for the Fur- and iron-dependent activation of the fum $A$ gene. A somewhat similar mechanism has been suggested for the Furmediated activation of the bacterioferritin gene (Andrews et al., 1989). Comparable searches of the fum $C$ sequence revealed a putative Fur site in the fum $C$ promoter region (coordinates 2108-2126; Woods et al., 1986) but none were located in the fum $B$ sequence.

The SoxRS two-stage regulatory system positively regulates genes such as the superoxide dismutase $\mathrm{A}(\operatorname{sod} A)$ and glucose-6-phosphate dehydrogenase $(z w f)$ genes, which have roles in defending $E$. coli against superoxidegenerating agents. The results obtained with the acn-lac $Z$ 
and fum-lac $Z$ fusions now confirm that $\operatorname{acn} A$ and $f u m C$ are members of the soxRS regulon. Previous studies have shown that aconitase is particularly sensitive to oxidative attack, leading to the suggestion that its inactivation performs a protective role in shutting down metabolic electron flow so as to halt the further production of superoxide radicals (Gardner \& Fridovich, 1991, 1992). Further studies with fumarase indicated that the SoxRS system also operates to replace unstable enzymes such as FumA and FumB, by a stable isoenzyme like FumC, which is better able to withstand oxidative attack (Liochev \& Fridovich, 1992). The observed soxR-dependent induction of acn $A-l a c Z$ expression by superoxide probably represents a compensatory response invoked to maintain or restore cellular aconitase activity under conditions of severe enzyme inactivation by oxidative attack. The response to oxidative stress could thus involve two phases, an immediate response in which $A c n A, A c n B$, FumA and FumB are rapidly inactivated in order to limit intracellular damage, followed by a delayed response in which the SoxRS-induced production of AcnA and FumC replaces the inactivated enzymes so as to maintain metabolism or to promote its restoration once the stress has diminished.

A SoxS binding-site consensus has yet to be defined, but attention has been drawn to an $18 \mathrm{bp}$ motif (ACCC---GAAAA--A-G) present in the sod $A$ and zwf promoters (Compan \& Touati, 1993). It may thus be significant that an almost identical motif occurs upstream of the $\operatorname{acn} A$ coding region (coordinates 1186-1203; Prodromou et al., 1992). No such motif was detected in the fum $C$ promoter region, but there are regions of partial dyad symmetry which might provide more appropriate binding sites for a member of the AraC family of regulators, such as SoxS.

This work presents the first evidence for the existence of at least two aconitases in a single bacterial species. Current studies are aimed at characterizing the residual enzyme activity $(A c n B)$ in the acn $A$ mutant and the corresponding gene $(a c n B)$ in order to understand the metabolic basis for the presence of aconitase isoenzymes in E. coli. It will be particularly interesting to determine whether $\mathrm{AcnB}$ more closely resembles the mitochondrial aconitase than AcnA and whether either has an iron-responsive regulatory function like the mammalian iron regulatory factor.

\section{ACKNOWLEDGEMENTS}

We are very grateful to Rachel Copeland for assistance with some of the lac $Z$ fusion studies, to those who kindly contributed bacterial strains and plasmids, and to Dr S. C. Andrews and Dr J. Green for advice and helpful discussions. We are also grateful to Dr W. J. E. Gardner and Dr A. G. Brooke (Haarmann \& Reimer, Selby) and the Science and Engineering Research Council for a CASE Studentship.

\section{REFERENCES}

Amabile-Cuevas, C. F. \& Demple, B. (1991). Molecular characterization of the soxRS genes of Escherichia coli: two genes control a superoxide stress regulon. Nucleic Acids Res 19, 4479-4484.
Andrews, S. C., Harrison, P. M. \& Guest, J. R. (1989). Cloning, sequencing and mapping of the bacterioferritin gene (bfr) of Escherichia coli K-12. J Bacteriol 171, 3940-3947.

Bagg, A. \& Neilands, J. B. (1987). Ferric uptake regulation protein acts as a repressor, employing iron (II) as a cofactor to bind the operator of an iron transport operon in Escherichia coli. Biochemistry 26, 5471-5477.

Bell, P. J., Andrews, S. C., Sivak, M. N. \& Guest, J. R. (1989). Nucleotide sequence of the FNR-regulated fumarase gene (fumB) of Escherichia coli K-12. J Bacteriol 171, 3494-3503.

Chambers, S. P., Prior, S. E., Barstow, D. A. \& Minton, N. P. (1988). The pMTL nic cloning vectors. Improved pUC polylinker regions to facilitate the use of sonicated DNA for nucleotide sequencing. Gene 68, 139-149.

Cole, S. T. \& Guest, J. R. (1980). Genetic and physical characterization of lambda transducing phages $(\lambda f r d A)$ containing the fumarate reductase gene of Escherichia coli K12. Mol \& Gen Genet 178, 409-418.

Compan, I. \& Touati, D. (1993). Interaction of six global transcription regulators in expression of manganese superoxide dismutase in Escherichia coli K12. J Bacteriol 175, 1687-1696.

Compan, I. \& Touati, D. (1994). Anaerobic activation of $\operatorname{arc} A$ transcription in Escherichia coli: roles for Fnr and ArcA. Mol Microbiol 11, 955-964.

Constable, A., Quick, S., Gray, N. K. \& Hentze, M. W. (1992). Modulation of the RNA-binding activity of a regulatory protein by iron in vitro: switching between enzymatic and genetic function. Proc Natl Acad Sci USA 89, 4554-4558.

Emery-Goodman, A., Hirling, H., Scarpellino, L., Henderson, B. \& Kuhn, L. (1993). Iron regulatory factor expressed from recombinant baculovirus : conversion between the RNA-binding apoprotein and $\mathrm{Fe}-\mathrm{S}$ cluster containing aconitase. Nucleic Acids Res 21, 1457-1461.

Flint, D. H., Emptage, M. H. \& Guest, J. R. (1992). Fumarase A from Escherichia coli: purification and characterization as an iron-sulfur containing enzyme. Biochemistry 31, 10331-10337.

Gardner, P. R. \& Fridovich, I. (1991). Superoxide sensitivity of the Escherichia coli aconitase. J Biol Chem 266, 19328-19333.

Gardner, P. R. \& Fridovich, I. (1992). Inactivation-reactivation of aconitase in Escherichia coli-a sensitive measure of superoxide radical. J Biol Chem 267, 8757-8763.

Gray, C. T., Wimpenny, J. W. T. \& Mossman, M. R. (1966). Regulation of metabolism in facultative bacteria. II. Effects of aerobiosis and nutrition on the formation of Krebs cycle enzymes in Escherichia coli. Biochim Biopbys Acta 117, 33-41.

Greenberg, J. T., Monach, P., Chou, J. H., Josephy, D. \& Demple, B. (1990). Positive control of a global antioxidant defense regulon activated by superoxide-generating agents in Escherichia coli. Proc Natl Acad Sci US A 87, 6181-6185.

Guest, J. R. (1981). Partial replacement of succinate dehydrogenase function by phage- and plasmid-specified fumarate reductase in Eschericbia coli. J Gen Microbiol 122, 171-179.

Guest, J. R. \& Russell, G. C. (1992). Complexes and complexities of the citric acid cycle in Escherichia coli. Curr Top Cell Regulation 33, 231-247.

Guest, J. R., Angier, S. J. \& Russell, G. C. (1989). Structure, expression, and protein engineering of the pyruvate dehydrogenase complex of Escherichia coli. Ann NY Acad Sci 573, 76-99.

Haile, D. J., Rouault, T. A., Harford, J. B., Kennedy, M. C., Blondin, G. A., Beinert, H. \& Klausner, R. D. (1992a). Cellular regulation of the iron-responsive element binding protein: disassembly of the cubane iron-sulfur cluster results in high-affinity RNA binding. Proc Natl Acad Sci US A 89, 11735-11739. 
Haile, D. J., Rouault, T. A., Tang, C. K., Chin, J., Harford, J. B. \& Klausner, R. D. (1992b). Reciprocal control of RNA-binding and aconitase activity in the regulation of the iron-responsive element binding protein : role of the iron-sulfur cluster. Proc Natl Acad $S_{c i}$ US A 89, 7536-7540.

Hamilton, C. M., Aldea, M., Washburn, B. K., Babitzke, P. \& Kushner, S. R. (1989). New method for generating deletions and gene replacements in Escherichia coli. J Bacteriol 171, 4617-4622.

Hidalgo, E. \& Demple, B. (1994). An iron-sulfur center essential for transcriptional activation by the redox-sensing SoxR protein. EMBO J 13, 138-146.

luchi, S. \& Lin, E. C. C. (1988). $\operatorname{arc} A(d y e)$, a global regulatory gene in Escberichia coli mediating repression of enzymes in aerobic pathways. Proc Natl Acad Sci USA 85, 1888-1892.

Jin, S. F. \& Sonenshein, A. L. (1994). Identification of two distinct Bacillus subtilis citrate synthase genes. J Bacteriol 176, 4669-4679.

Kaptain, S., Downey, W. E., Tang, C., Philpott, C., Haile, D., Orloff, D. G., Harford, J. B., Rouault, T. A. \& Klausner, R. D. (1991). A regulated RNA binding protein also possesses aconitase activity. Proc Natl Acad Sci US A 88, 10109-10113.

Kennedy, M. C., Emptage, M. H., Dreyer, J-L. \& Bienert, H. (1983). The role of iron in the activation-inactivation of aconitase. $J$ Biol Chem 258, 11098-11105.

Kennedy, M. C., Mende-Mueller, L., Blondin, G. A. \& Beinert, H. (1992). Purification and characterization of cytosolic aconitase from beef liver and its relationship to the iron-responsive element binding protein. Proc Natl Acad Sci US A 89, 11730-11734.

Klausner, R. D. \& Rouault, T. A. (1993). A double life: cytosolic aconitase as a regulatory RNA binding protein. Mol Biol Cell 4, 1-5.

Laemmli, U. K. (1970). Cleavage of structural proteins during the assembly of the head of bacteriophage T4. Nature 277, 680-685.

Lakshmi, T. M. \& Helling, R. B. (1976). Selection for citrate synthase deficiency in icd mutants of Escherichia coli. J Bacteriol 127, 76-83.

Liochev, S. I. \& Fridovich, I. (1992). Fumarase C, the stable fumarase of Escherichia coli, is controlled by the soxRS regulon. Proc Natl Acad Sici US A 89, 5892-5896.

Miles, J. M. \& Guest, J. R. (1984). Complete nucleotide sequence of the fumarase gene fum $A$ of Escherichia coli. Nucleic Acids Res 12, $3631-3642$.

Miller, J. H. (1972). Experiments in Molecular Genetics. Cold Spring Harbor, NY: Cold Spring Harbor Laboratory.

Minton, N. (1984). Improved plasmid vectors for the isolation of translational lac gene fusions. Gene 31, 269-273.

Niederhoffer, E. C., Naranjo, C. M., Bradley, K. L. \& Fee, J. A. (1990). Control of Escherichia coli superoxide dismutase (sod $A$ and $s o d B$ ) genes by the ferric uptake regulation (fur) locus. $J$ Bacteriol 172, 1930-1938.
Patton, A. J., Hough, D. W., Towner, P. \& Danson, M. J. (1993). Does Escherichia coli possess a second citrate synthase gene? Eur $J$ Biochem 214, 75-81.

Perham, R. N. (1990). Genes, proteins and metabolic functions of enzymes. In Genetics and Human Nutrition, pp. 1-14. Edited by P. J. Randle, J. I. Bell \& J. Scott. London: John Libbey.

Prodromou, C., Haynes, M. J. \& Guest, J. R. (1991). The aconitase of Escherichia coli: purification of the enzyme and molecular cloning and map location of the gene (acn). J Gen Microbiol 137, 2505-2515.

Prodromou, C., Artymiuk, P. J. \& Guest, J. R. (1992). The aconitase of Escherichia coli: nucleotide sequence of the aconitase gene and amino acid sequence similarity with mitochondrial aconitases, the iron-responsive-element-binding protein and isopropylmalate isomerases. Eur J Biochem 204, 599-609.

Reaney, S. K., Bungard, S. J. \& Guest, J. R. (1993). Molecular and enzymological evidence for two classes of fumarase in Bacillus stearotbermophilus (var. non-diastaticus). J Gen Microbiol 139, 403-416.

Richarme, G. (1989). Purification of a new dihydrolipoamide dehydrogenase from Eschericbia coli. J Bacteriol 171, 6580-6585.

Robbins, A. H. \& Stout, C. D. (1989). Structure of activated aconitase: formation of the [4Fe-4S] cluster in the crystal. Proc Natl Acad Sci US A 86, 3639-3643.

Sambrook, J., Fritsch, E. F. \& Maniatis, T. (1989). Molecular Cloning: a Laboratory Manual, 2nd edn. Cold Spring Harbor, NY: Cold Spring Harbor Laboratory.

Silhavy, T. J., Barman, M. L. \& Enquist, L. W. (1984). Experiments with Gene Fusions. Cold Spring Harbor, NY: Cold Spring Harbor Laboratory.

Spiro, S. \& Guest, J. R. (1987). Regulation and over-expression of the fnr gene of Eschericbia coli. J Gen Microbiol 133, 3279-3288.

Spiro, S., Roberts, R. E. \& Guest, J. R. (1989). FNR-dependent repression of the ndh gene of Escherichia coli and metal ion requirement for FNR-regulated gene expression. Mol Microbiol 3, 601-608.

Woods, S. A. \& Guest, J. R. (1987). Differential roles of the Escherichia coli fumarase and $f n r$-dependent expression of fumarase $\mathrm{B}$ and aspartase. FEMS Microbiol Lett 48, 219-224.

Woods, S. A., Miles, J. S., Roberts, R. E. \& Guest, J. R. (1986). Structural and functional relationships between fumarase and aspartase: nucleotide sequences of the fumarase (fumC) and aspartase $(\operatorname{asp} A)$ genes of Escherichia coli K12. Biochem $J$ 237, $547-557$.

Woods, S. A., Schartzbach, S. D. \& Guest, J. R. (1988). Two biochemically distinct classes of fumarases in Escherichia coli. Biochim Biophys Acta 954, 14-26.

Received 5 April 1994; revised 16 June 1994; accepted 21 June 1994. 